\title{
Revolution of the Solitaries, Arsenius the Great, and Socrates. An Early Theological Justification of the Radical Monastic Detachment from Society
}

For Michael M. Pozdnev

\section{Dmitrij F. Bumazhnov}

Göttingen University, Humboldtallee 17, Göttingen, D-37073; bumazhnov@gmx.net

For citation: Dmitrij F. Bumazhnov. Revolution of the Solitaries, Arsenius the Great, and Socrates. An Early Theological Justification of the Radical Monastic Detachment from Society. Philologia Classica 2020, 15 (1), 72-87. https://doi.org/10.21638/spbu20.2020.106

The article investigates an early theological justification of the radical detachment from society expressed in a saying by the famous Egyptian hermit Arsenius the Great $\left(4^{\text {th }}-5^{\text {th }}\right.$ century) who avoided contacts not only with lay people, but even with his fellow monks in the desert of Sketis. This justification is to be seen in connection with the phenomenon of monastic secluded life which suddenly emerged in the second part of the $3^{\text {rd }}$ century, in sharp contrast with traditional views of the catholic Christians of the $1^{\text {st }}-3^{\text {rd }}$ centuries on the way of life suitable for the followers of Christ. In this article, the radical break with this early paradigm is called the "revolution of the solitaries". Arsenius, who lived about eighty years after the first monks in Egypt started to be recognized as a distinct phenomenon in public space, does not necessarily draw on the oldest layers of the traditions justifying and explaining the religious motivation for being alone. Nevertheless, his statement is one of the first pieces of theological reflection on the subject transmitted in full which opens a number of intriguing possibilities for further research on this widely neglected field. The article provides the historical context of Arsenius' justification which includes criticism of the anachoretic monasticism in the pagan and Christian communities. Some critics of the secluded life consider it as contrary to the Jewish and pagan wisdom as well as to the revelation of Christ, a statement making Arsenius' apology most precarious. Of special inrerest is that Arsenius, when staying away remaining secluded from all kinds of people, was to a certain degree guided by the example of Socrates.

Keywords: early Egyptian monasticism, Arsenius the Great, Socrates, eremitism

\section{Introduction}

In the second part of the $3^{\text {rd }} \mathrm{c}$. $\mathrm{AD}$, a revolutionary paradigm shift in Christian ideology appeared in which the previous appreciation of communal life and being together started to be replaced by high esteem for the prolonged solitary life, a way of life up to that time almost completely unknown both in the two Testaments and in the pagan world. Resulting in the monastic movement, this shift shaped the Christian churches and late antique, medieval and modern society more deeply than any other movement within Christianity. All the more surprising is that the last comprehensive attempt to account for

(C) St. Petersburg State University, 2020 
reasons of this revolution and to explain its main lines of development historically was made in 1936 by Karl Heussi. ${ }^{1}$ Since then, a tremendous amount of pertinent material has been collected in diverse areas, yet a coherent synthesis mapping the relevant features of early monasticism as a whole, and a related reflection plausibly explaining the reasons for this phenomenon's emergence are still missing. The present article does not raise the impossible claim of filling this gap; rather I would like to point at the problem in question and make a step towards its solution by using so far unstudied evidence from the Apophthegmata Patrum.

The Greek Alphabetical Collection (AC) of the sayings of the Egyptian desert fathers (Apophthegmata Patrum) ${ }^{2}$ begins with 38 sayings by the father of the monks Antony the Great. Obviously, putting Antony's apophthegmata first, the collection's compilers wanted to emphasize his paramount importance for the entire early monastic movement. Ranking second after Antony follow sayings attributed to St. Arsenius the Great. This position possibly has likewise to do with the high esteem which Arsenius enjoyed among the people responsible for compiling the AC. ${ }^{3}$ Already first brief acquaintance with the 44 sayings by Arsenius transmitted here ${ }^{4}$ reveals that both Arsenius' contemporaries as well as compilers of the AC were highly impressed by the personality of the Saint. A more careful analysis reveals that features felt as most astonishing were his consequent avoiding contacts with all people regardless of their age, gender, place in society or position in the Church as well as Arsenius' pre-monastic life. ${ }^{5}$ As for Arsenius' life before becoming a monk, the sayings allude to the widespread tradition according to which Arsenius obtained a prominent po-

${ }^{1}$ Cf. Heussi 1936. Another monographic investigation, Nagel 1966, is not entirely dedicated to studying the problems of monasticism's origin. Among various non-monographic attempts after Heussi to shed new light on the problem of origin of monasticism, one can refer to Guillaumont 1979, Goehring 1999, Harmless 2004, 417-469, Caner 2012 and Bumazhnov 2017.

2 About the literary genre of the Greek monastic Apophthegmata Patrum, see Pauli 2002 and Guy 2013, 18-21. This genre comprises stories and sayings attributed to the known and unknown desert monks who lived mostly in the deserts of Egypt and Palestine starting from the middle of the $4^{\text {th }}$ cent. After a period of oral transmission, Apophthegmata had been written down probably by the end of the $5^{\text {th }}$ - beginning of the $6^{\text {th }}$ cent. in Palestine. In this time, the first Alphabetic and Systematic (i.e. organized in chapters according to central themes in monastic asceticism) Collections appeared, cf. Smith 2017, 31-36. For the current stage of research of the sayings see Rubenson 2013 who, in my opinion, tends to underestimate the value of the Apophthegmata Patrum as historical sources for the $4^{\text {th }}-$ early $5^{\text {th }}$ cent. monasticism.

${ }^{3}$ Generally, in the Greek AC after names starting with "A", follow those starting with "B", " $\Gamma$ ", " $\Delta$ " etc., but within a respective letter no alphabetical order is maintained, cf. the sequence of names starting with "A": Antony, Arsenius, Agathon, Ammonas, Achilles, Ammoes, Amoun of Nitria, Anoub, Abraham, Ares, Alonius, Apphy, Apollo, Andrew, Aio, Ammonathas. Thus, the second place after Antony may perhaps reflect a certain degree of esteem. Guy 2013, 75 n. 6 refers to two sayings from the Anonymous Collection in which Arsenius is characterized as the epitome of the true anachoretic life. Arsenius' sayings served as spiritual guidance for the great Syriac hermit Isaac of Nineveh (second part of the $7^{\text {th }}$ cent.), see below, n. 82. Finally, some details of Arsenius' life had been borrowed by the unknown author of the Syriac Story of Arsānis which represents a branch in the widespread Christian-Muslim tradition about talking skull; about research history of this tradition see Bumazhnov 2010, 108-113 and Grypeou 2016; for the English translation of the Story, see Hall 1889/1890, 85-88. Cf. also n. 22 about Arsenius Monastery in Țurā.

4 There is no critical edition of the Greek AC.I quote the Greek text according to Migne 1864, 87B-108D; for English translation see Ward 1984, 9-19.

5 Avoiding people: Ars. 1-2 (God commands Arsenius to flee from human beings), 7-8 (avoiding meeting with bishops), 11 (not leaving one's cell), 13, 26, 28, 34, 37, 38, 44 (avoiding contacts with monks and laypeople), 31 (avoiding contacts with all kinds of people). Arsenius' pre-monastic life: Ars. 1, 4, 18, 36, 42; Arsenius' high education level resulting from his pre-monastic life: Ars. 5, 6. The numbers refer to Arsenius' sayings in the AC. 
sition at the court of Theodosius I (Roman Emperor from $379, \uparrow 395$ ) and played a certain role in upbringing of the Emperor's sons Arcadius (377-408) and Honorius (384-423) who ruled respectively Eastern (395-408) and Western (395-423) Roman Empire.

Is it possible to see any link between these two unusual features that imprinted themselves so sharply into contemporaries' and compilers' minds? Why would being alone be surprising even among the desert monks who are normally considered to have been predisposed to this style of life, or at least to have chosen it in a free manner? It is my purpose to try answering these questions. The present essay endeavors to explain why Arsenius' consequent detachment from society was bewildering even for his brother monks in the Egyptian desert. Besides, I would like to comment on the theological justification which Arsenius used to face their reproaches; finally, a possible relationship between Arsenius' secluded life and Socrates shall be scrutinized. Before proceeding to an analysis of the respective texts, I will provide some details concerning Arsenius' biography and its sources and outline the general historical and theological context regarding his desire to be left alone.

\section{Arsenius' Biography and its Sources}

Apart from the Apophthegmata Patrum mentioned above, we have a couple of hagiographical sources providing various information about the life of the Saint. In terms of historical significance, the most important among them is the unpublished Life BHG $167 \mathrm{z}^{6}$ consisting of two parts. ${ }^{7}$ Its first part, the so-called Roman Novel, does not belong to the text's older layers. It reports on Arsenius' way of life before his becoming a monk. D. E. Afinogenov believes that the Roman Novel was written in the $8^{\text {th }}$ century in Rome and provides a reconstruction of its earliest translation into Greek. ${ }^{8}$ In the Novel, Arsenius is depicted as descendant of a noble Roman family. Highly valuing his great learning and knowledge of Greek and Roman wisdom, the Emperor Theodosius I appoints him as the teacher $(\pi \alpha \text { เ } \delta \varepsilon v \tau \eta \varphi)^{9}$ of his sons, the future Emperors Arcadius and Honorius. After serving fourteen years in the post, Arsenius withdraws to the desert of Sketis. ${ }^{10}$

In its core, the Roman Novel draws on the tradition according to which Arsenius was the childhood educator and teacher of Theodosius' sons. ${ }^{11}$ Its oldest form is transmitted

6 The abbreviation refers to Bibliotheca Hagiographica Graeca, see Halkin 1957, 63.

7 For later documents see Vasil'evsky 1897, 354-375, Garitte 1955, 260 n. 4 and Afinogenov 2004. As it appears, these sources are devoid of any historical significance. Leppin 2003, 127-128, 152-153 relies on some of them rather uncritically. The reprint of Vasil'evsky's article published in a separate book (Vasil'evsky 1899) was not available for me.

8 See Afinogenov 2004, 56-59. The Latin original text is lost; Afinogenov suggests that it had been reworked rather considerably in a Greek milieu.

${ }^{9}$ Afinogenov 2004, 56.

10 The Sketis Valley in the North-West Egypt is more commonly known as the Wadi al-Natrun situated in the Libyan Desert about $65 \mathrm{~km}$ south-west of the Nile Delta. In the narrow sense of the word, Sketis

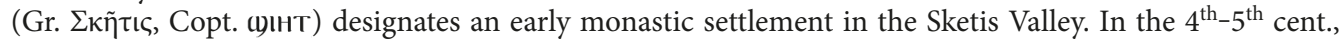
the Sketis monks lived separately each in his own cell spread out throughout the desert and came together for weekly prayers and feast days, cf. Evelyn White 1932, 17-42, 210-211, Cody 1991, Smith 2017, 31-32. Arsenius' sayings testify that he had spent a considerable part of his life in Sketis (cf. Ars. 20, 21, 36, 42); according to Ars. 42, he lived there for forty years. However, this number of years raises doubts due to the numerous biblical precedents.

11 A later version of this tradition is preserved in the Life of Euthymius the Great 21 by Cyril of

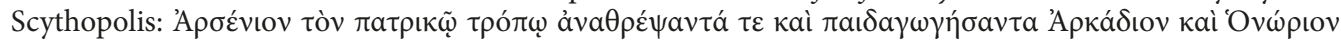

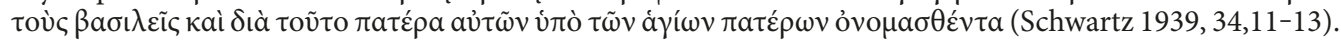


in Ars. 36 and 42 where Arsenius is called "father" of the Emperors Arcadius and Honorius without any further details. ${ }^{12}$ The two sayings do not relate that Arsenius was given this title in the desert as it is the case in the Life of Euthymius 21; neither do we find here an explanation of the title, a fact which is to be seen as a sign of antiquity of this tradition. ${ }^{13}$

V. G. Vasil'evsky suggests that the word "father" in the sayings Ars. 36 and 42 is to be understood as "court official title". ${ }^{14}$ Summarizing his learned excursion about Arsenius' position at the court Vasil'evsky observes: "Since the rite of baptism at that time did not necessarily follow immediately after birth, it is quite possible that the two [princes] had been baptized simultaneously and therefore had one and the same godfather who afterwards became their childhood educator and teacher." 15

I turn now to the second part of the unpublished life BHG 167z. According to Chiara Faraggiana di Sarzana, it contains all 44 sayings transmitted in the AC with "a few additional passages [...] in exactly the same order and with basically the same text". ${ }^{16} \mathrm{Di}$ Sarzana suggests that the second part of BHG $167 \mathrm{z}$ and the AC Arsenius's sayings have their origin in the oral narratives by Arsenius' pupil Daniel ${ }^{17}$ which were written down in Palestine in the circle of St. Euthymius $\left({ }^{*}\right.$ c. $\left.377-\dagger 473\right) .{ }^{18}$ This suggestion is not unfounded: in Euthymius' Life mentioned above we read that the Saint "heard with joy [...] details of [the] life" of the Great Arsenius who "at this time was resplendent with virtues in the Egyptian desert". These "details" were recounted by "the venerable fathers" coming "to him at various times from Egypt". ${ }^{19}$ It is worth noting that, according to this source, the

"Arsenius [...], who had reared and educated the emperors Arcadius and Honorius in the manner of a father, and for this reason was called their father by the holy fathers." Translation: Price 1991, 30. The Life was written in 555-557, cf. Festugière 1962, 10 and the Life of Euthymius 60 (Schwartz 1939, 83).

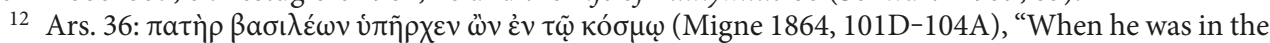

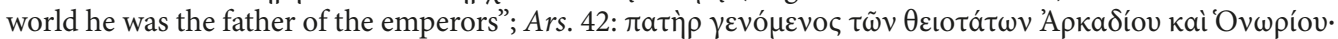
(Migne 1864, 108A), "he was the father of the divine Arcadius and Honorius". Unless indicated otherwise all translations are mine; Ward 1984, 17, 19 misunderstands both sentences.

13 Cf. the Life of Euthymius 21 (see n. 11 above) clarifying that Arsenius was bringing up Theodosius' sons. Another explanation is provided by the Vitae Patrum III 37 by Pseudo-Rufinus saying that Arsenius was the godfather of the future Emperors, cf. Migne 1849, 762D-763A: Fuit quidam vir in palatio sublimus, sub Theodosio imperatore, nomine Arsenius, cujus filios, id est Arcadium et Honorium Augustus de baptismo suscepit. "A man named Arsenius had gained a position of prominence at the court of the Emperor Theodosius whose sons, the Augusti Arcadius and Honorius, he received from the baptismal font." Vasilevsky 1897, 359, n. 2 rightly emends Augustus to Augustos. The third book of the Vita Patrum is a little-explored independent collection of Latin Apophtegmata Patrum and other monastic texts. Freire 1973, 167 characterizes its first part, Vita Patrum III 1-40 comprising also Vitae Patrum III 37, as "un traité dont on avait perdu le souvenir". Cremascoli 2014, 22 does not add anything new to this statement.

14 Vasil'evsky 1897, 360.

15 Vasil'evsky 1897, 359-363 (excursion), quotation: 362. Of the same opinion is also Afinogenov 2004, 55.

${ }^{16}$ Faraggiana di Sarzana 1997, 456-457. Di Sarzana refers to four manuscripts containing BHG 167z (ibid. 456). I was able to use Codex Vaticanus gr. 1589 ( $10^{\text {th }}$ cent.); its text, however, does not always match the description provided by Faraggiana di Sarzana. Di Sarzana prefers to leave the question open as for the exact relationship between the two sources (i.e. BHG $167 \mathrm{z}$ and 44 Arsenius' sayings from the AC) (ibid. 459).

17 Abba Daniel is introduced as narrator in Ars. 14, 17-19, 23, 26, 29, 33-35, 39, 42-43. Cf. also Daniel 6-7 and Agathon 28.

18 Faraggiana di Sarzana 1997, 457-458.

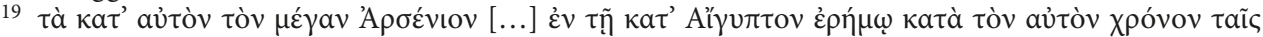

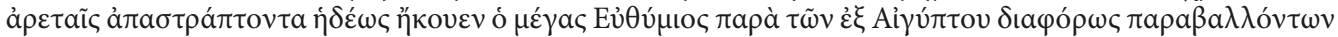

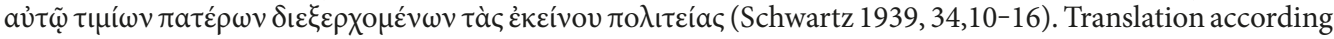
to Price 1991, 30. The author of St. Euthymius' Life Cyril of Scythopolis ( $†$ c. 559) received and recorded this information during his conversations with Abba Cyriacus $\left({ }^{\star} 449-\dagger 557\right.$; cf. Life of Euthymius 21 and 60 ; 
oral narratives about Arsenius reached Euthymius when the former was still alive. ${ }^{20}$ Thus, as it appears, there is some evidence that both the Greek sayings from AC and the second part of Arsenius' Life BHG 167z go back to quite early written records of the oral Egyptian traditions about St. Arsenius. ${ }^{21}$

In Ars. 42, Arsenius' pupil Abba Daniel lists the most important stages of his teacher's life in chronological sequence. According to Daniel, Arsenius lived for forty years at Theodosius' court and the same number of years in Sketis, then ten years in Troe ${ }^{22}$ opposite the city of Memphis at south-east of Old Cairo, three years in Canopus near Alexandria, and finally two more years in Troe where he died. ${ }^{23}$ There are good reasons to question the two equal forty year periods at the court and in the desert because of their numerous prototypes in the Bible where forty years or days usually symbolize a time of testing. ${ }^{24}$ Afinogenov remarks that, in this chronology, only the last fifteen years look plausible and it was probably during this time that Daniel did know Arsenius personally and possibly lived with him. ${ }^{25}$ Evelyn White, when overlooking this difficulty and asserting that the withdrawal in the desert occurred in 394, believes that Arsenius died in 449. ${ }^{26}$ This arrangement of dates has been accepted by some scholars. ${ }^{27}$ The refinement of chronological framework goes beyond the scope of the present study, therefore I would like merely to emphasize that Arsenius' chronology as reconstructed by Evelyn White should not be considered absolutely reliable.

\section{Solitary Life and Detachment from Society}

When dealing with Arsenius' sayings it is worth bearing in mind that they went through an editing process as it was likewise the case with the rest of AC. ${ }^{28}$ Obviously, this implies that the editors' perspective on the Saint's deeds and words does not necessarily coincide with the perception of eyewitnesses and bearers of the oral tradition. This variety of perspectives can also be observed in the sayings dealing with Arsenius' avoiding people.

Schwartz 1939, 34,1-3; 82,28-83,7). Cyriacus' informants were monks who had lived with Euthymius "for a considerable time" (Life of Euthymius 21; Price 1991, 29).

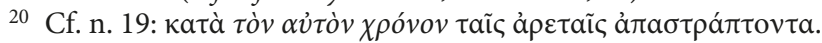

21 This evidence runs counter to Samuel Rubenson's thesis that "the collection of apophthegmata preserved in our manuscripts cannot be used for a reconstruction of fourth-century conditions and events, but only as a source for the educational activities of late fifth and sixth century monasteries", Rubenson 2013, 19, cf. also n. 12 above.

22 The Greek transcription in Ars. 43 is Tpón; in other Greek sources, this place is known since the $3^{\text {th }}$ cent. BC as Tpoía or Tpwía, its modern Arabic name is Țurā, cf. Timm 1992, 2882. The now ruined monastery Dayr al-Qușayr, also known as Dayr Arsaniyus (i.e. Arsenius Monastery) in TTurā, is believed to have been built over the tomb of Arsenius by the Emperor Arcadius, whose tutor Arsenius had been. In 1941, the so-called Tura Papyri (mostly works of Origen and Didymus the Blind) were found in Țurā, cf. Coquin/Martin 1991. Some scholars suggest that they originated from Arsenius Monastery, s. Garitte 1955, 260 n. 5.

${ }^{23}$ Migne 1864, 108A.

${ }^{24}$ E. g. Moses was $(40 \times 3=) 120$ years old when he died (Deut. 34:7); following the exodus from Egypt, he lived 40 years in the desert with his people (Deut. 2:7) and remained for forty days and nights on Mount Sinai (Ex. 34:28).

25 Afinogenov 2004, 55.

26 Evelyn White 1932, 122-123 (withdrawal in the desert in 394 shortly before the death of Theodosius in 395), 162-163 (leaving the Sketis forty years later in 434, Arsenius' death fifteen more years later in 449).

27 Cf. e.g. Moreschini 1962, Chitty 2007, 121, Guy 2013, 74-77.

28 This is rightly emphasized by Rubenson 2013, 17-21. 
The collection of Arsenius' apophthegmata opens with two short stories (Ars. 1, 2) justifying his unwillingness to see all types of human beings. While still living in the palace, Arsenius prays to God begging to show him the way of salvation. A voice answers him: "Arsenius, flee from men and you will be saved." ${ }^{29}$ After becoming a monk, Arsenius repeats this prayer again and hears essentially the same answer in a slightly expanded form: "Arsenius, flee, be silent, [and] remain tranquil [in prayer], for these are the sources of sinlessness." 30 It is not hard to see that it was the collection's compilers who put the twice

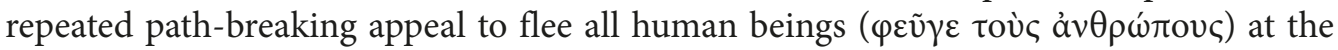
beginning of 44 Arsenius' sayings. Hence, we can infer that, at the point when Arsenius' sayings were recorded in their present form, the radical avoiding all contacts with people ${ }^{31}$ was regarded as a highly-esteemed monastic paradigm worth emulating.

A completely different impression emerges if we read Arsenius' apophthegmata from the point of view of his visitors whom he refused to communicate with. These people display a wide range of emotions starting from polite acceptance of given circumstances and reaching up to surprise, discontent, and resentment. ${ }^{32}$

Ars. 38 provides an appropriate illustration. The story tells of an unknown brother who comes to see Arsenius at Sketis. Arsenius' cell was "far away", so one of the monks escorted him to the place. Frequently enough, Arsenius simply refused to accept visitors ${ }^{33}$ but this time he chose another tactic - silence. After it had become clear that no conversation was possible, the brother left and asked to take him to Abba Moses who "welcomed" him and his guide "joyfully and treated them hospitably". In response to the guide's question, "which of the two" does he "prefer?" 34 the brother opts for Abba Moses. The saying culminates in a vision which sets aright his all too human choice. Its meaning seems to be that, though in God's eyes Abba Moses is indisputably a great monk, Arsenius deserves a higher place. ${ }^{35}$

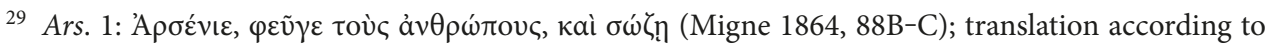
Ward 1984, 9.

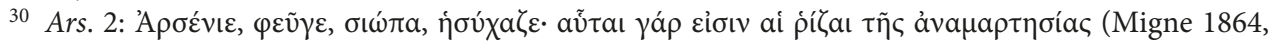
88C); translation according to Ward 1984, 9 with small modifications. Cf. chapter 58 from a letter by St. Arsenius transmitted in Old Georgian, I quote the Latin translation by Garitte 1955, 273: Arsenius, Letter 58: Si non secedes ab hominibus, non potes monachus esse.

31 The reinforced repetition of the divine plea in Arc. 2 probably means that it applies not only to laypeople, but likewise to monks. On the other hand, one should not overestimate the degree in which this way of life was implementable even for such a devoted recluse as Arsenius the Great. From his sayings we can see that Arsenius met his pupils on a regular basis, and from time to time did speak also to other Sketis monks; Ars. 38 mentions e.g. the common prayer in one of the Sketis' churches.

${ }^{32}$ Cf. Ars. 8, 13, 26, 28, 37, 38.

${ }^{33}$ Cf. Ars. 26, 28, 31, 32, 34, 37.

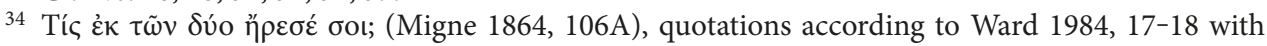
some modifications.

35 The vision (Migne 1864, 106A-B) was granted to an elder who had prayed to understand the matter. He was shown two large boats on a river. In one of them Abba Arsenius and the Spirit of God

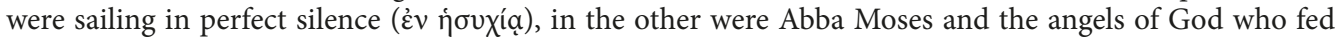
him with honeycomb. The position of the accompanying beings (Holy Spirit and angels) in the celestial hierarchy probably reflects the level of spiritual greatness of the respective monk. It is worth noting that Abba Arsenius is absorbed in deep contemplative silence (ívuxía) suitable for monks whereas Abba Moses is eating honey - symbol of God's word (cf. Ps 118:103) which he interiorizes presumably in order to pass it along to human beings. The latter activity is not specifically monastic. This contrast highlights that Arsenius' way of life, being approved by God or Holy Spirit Himself, is predominantly fitting for monks. 
Obviously, this theological interpretation contrasts sharply with the visitor's feelings and is designed to face possible criticism of Arsenius' conduct. It can be shown that such criticism perfectly fits into the historical context of the time. In what follows I will provide some evidence for this.

Arsenius belonged to the second generation of the Sketis monks. ${ }^{36}$ If he embraced the desert about $395 \mathrm{AD},{ }^{37}$ we have to assume about seventy or eighty years between this date and the time when Egyptian monks started to be perceived as a distinct social phenomenon. ${ }^{38}$ During this period, Christian monasticism managed to gain great popularity and a considerable number of passionate admirers. ${ }^{39}$ Much less known is Christian and pagan criticism of the early monastic movement. ${ }^{40}$ Among many subjects raised in this regard, I will focus on arguments against the secluded way of life and offer here a few examples.

The most serious objections against Christian eremitism were put forward by St. Basil of Caesarea $\left({ }^{*} \mathrm{ca} .330-\dagger 379\right)$ who, among other things, is known as theologian of coenobitic monasticism and promoter of Christian ascetic life in Asia Minor. ${ }^{41}$ In chapter 7 of the Great Asketikon, Basil writes about the style of life after withdrawal from the world. The question is whether it is appropriate "to live privately by himself", ${ }^{2}$ or to live "with brothers of the same mind" ${ }^{43}$ Basil answers that living together is of greater advantage in many ways,${ }^{44}$ and argues in the favor of this opinion using three groups of sources. ${ }^{45}$

36 Cf. Guy 2013, 54-63.

37 See n. 26 above.

${ }^{38}$ In the tract De patientia by Pseudo-Athanasius which was written probably in Egypt about $311 \mathrm{AD}$ the word $\mu$ ovaxoí does not yet designate monks as a separate group living outside the congregation, cf. Tetz 1990, 102. The earliest Egyptian papyrus evidencing this sense of the term rovaxó ৎ dates back in 324, cf. Judge 1977, Wipszycka 2001, Choat 2002. St. Pachomius founded his first monastery in the year 323, cf. Joest 1994 and Khosroev 2004, 48-49. According to the Life of the Blessed Antony the Great, written between 356 and 362 by Athanasius of Alexandria, the father of all monks was born around 251 and left the world behind being about twenty years of age, cf. Bartelink 2004, 42-43. Life of Antony 3,2-4 reports that at this time some Christian ascetics used to live on the border between the desert and the inhabited world near their own villages, but "no monk at all knew the great inner desert" (Greek text: Bartelink 2004, 136,9-10). No other evidence about monks in the $3^{\text {rd }}$ century is available, but there is little doubt that Christian monasticism was invented in the second part of this century. Regarding our research question, it is important that, by this time, monks are not yet present in the public awareness. About gradual appearance of monks in the $4^{\text {th }}$ and early $5^{\text {th }}$ century collective mind see Wipszycka 1997.

39 Revealing is St. Augustine's enthusiastic reaction to the Life of Antony which he read about 370-374, cf. Confessions 8:15 and De Vogüé 1991, 21-22 for the date. In the Syriac milieu, a good example can be provided by St. Ephraem the Syrian's (†373) hymns on the monks Julian Saba († 367) and Abraham Qidunaya ( $\dagger 1^{\text {st }}$ December 367); on those hymns and their text history see Griffith 1994 and Griffith 2004. For a comprehensive history of early monasticism see Desprez 1998, 155-545.

40 On this subject see Palanque/Bardy/de Labriolle 1947, 355-364, Teja 1988, Raynor 1989, Jiménez Sánchez 2010.

${ }^{41}$ Cf. Frazee 1980, Fatti 2010. Basil could have met Christian hermits during his journey to Syria, Palestine, and Egypt in 356 or 357, about this journey see Silvas, 2005, 100 (date) and Gain 2017. In 365, Basil was ordained as presbyter at Caesarea in Cappadocia; he started preaching ascetic life to the local Christians, answering their questions and giving them needed spiritual guidance. Resulting from these conversations were Lesser Rules or Lesser Asketikon, edited by Basil in 365-366, and framed in the form of questions and answers. Basil did not stop working on this book until the end of his life. The results of his efforts were Longer Monastic Rules, also called Longer Asketikon. For detailed information see Silvas, 2005, 143-145.

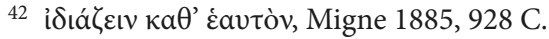

43 Translation according to Silvas, 2005, 180.

${ }^{44}$ Migne 1885, ibid.

45 Migne 1885, 928 C-933 C. 
His first argument is a silent reference to Plato's Republic and Aristotle's Politics: "First, simply with regard to bodily needs, not one of us suffices for himself alone, since we have need of each other for the provision of necessities." 46

The next two groups of arguments refer explicitly to the Old and New Testament. From the Old Testament, Basil chose Ecclesiastes 4:10: "Woe to him who is alone since when he falls there is no one to lift him up." ${ }^{37}$ Among numerous New Testament quotations one deserves special attention - Acts 2:44: "All believers were together and had all things in common". ${ }^{48}$ The "believers" in question are members of the very first Christian community in Jerusalem, i.e. apostles and people converted by them. Thus, Basil alludes to the apostolic ideal of living which is, according to him, incompatible with eremitism. This is a very strong argument and it is not by chance that Basil puts it at the end of his discourse.

Considering all three groups of sources together (Greek philosophy, Old and New Testament) we can realize the fundamental nature of Basil's criticism. He argues that coenobitic monasticism is supported by pagan and Hebrew wisdom as well as by the New Revelation at the same time. In the final analysis, one can see that the eremitic way of life clearly contradicts both the human nature and the Holy Scriptures accepted by Christians.

It should be noted that the perception of living apart from society through the lens of Plato's and Aristotle's philosophy was probably shared by the majority of people of that time educated in the spirit of classical paideia. As we know, Basil of Caesarea spent about five years in Athens studying classical rhetoric and philosophy as a pupil of Himerius and Prohaeresius. ${ }^{49}$ In 355, the future Emperor Julian paid a visit to Athens where he likewise associated himself with a circle of teachers, albeit partly different from that of Basil. ${ }^{50}$ Shortly before his death in 363 , Julian mentions Christian hermits in a letter using silent reference to the same set of ideas as Basil of Caesarea: ${ }^{51}$

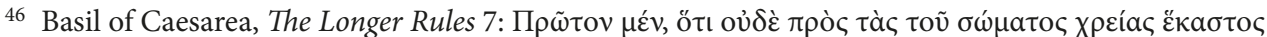

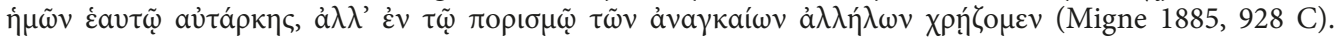

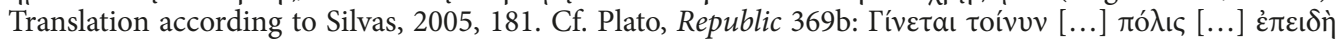

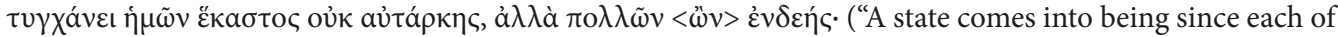
us is not independent, but actually needs the support of many people.") Greek text: Burnet 1902, translation:

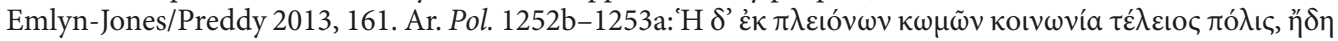

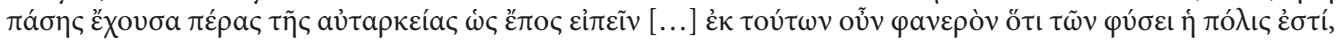

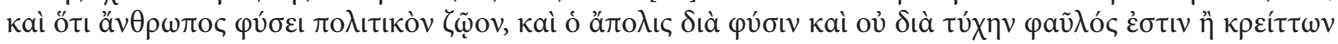

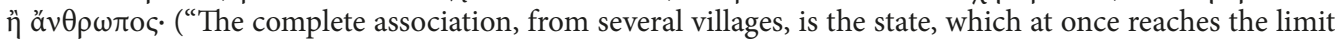
of total self-sufficiency, so to say. [...] These considerations make it clear, then, that the state is one of those things which exist by nature, and that man is by nature an animal fit for a state. Anyone who by his nature and not by ill-luck has no state is either a wretch or superhuman.") Greek text: Susemihl/Immisch 1929, 3,27-30.1-4, translation: Saunders 2000, 3.

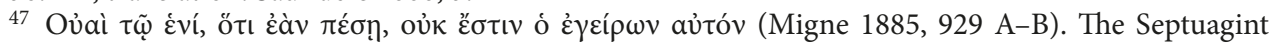
provides a slightly different text; Basil might have quoted from memory.

48 Translated according to the English Standard Version with small modifications. Greek text: Migne 1885,933 C.

49 Rousseau 1994, 27-60 dates this period back to 350-355 AD; cf. also Moreschini 2005, 13-14, 91-93. I thank Nikolai Lipatov-Chicherin who kindly provided me with these books.

50 Cf. Rousseau 1994, 33.

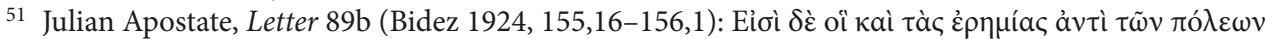
$\delta$ เ

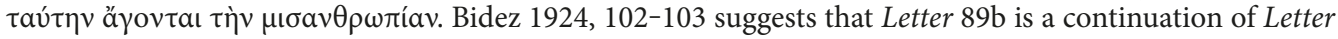
89a addressed to the pagan high priest Theodore; this view has been generally accepted, cf. Weis 1973, 306-307. 
There are [people] who seek [to live in] deserted places instead of cities, though man is by nature political and civilized being. ${ }^{52}$ [They do so because they are] dominated by the evil demons who impel them to hatred of mankind.

We find criticism of eremitism as a form of Christian life also in St. Jerome of Stridon. His comments are less fundamental, but much more emotional than those by Basil. In the letter addressed to Rusticus, a classically educated young lay monk living in Marseilles who requested a treatise about the virtues of the coenobitic monastic life, Jerome emphasizes that he is by no means against ascetically motivated living alone as such ${ }^{53}$ but, $^{2}$ nevertheless, he strongly advises Rusticus to opt for communal life. ${ }^{54}$ Jerome's concise statement of loyalty towards eremitism is completely overshadowed by ongoing denunciations of its various shortcomings in combination with frequent sarcastic remarks about failed hermits. ${ }^{55}$

Another path of early Christian discussion around ascetics preferring living alone can be reconstructed from the Letter to the Mountaineers falsely attributed to Ephrem the Syrian. Some remarks by the unknown author of the Letter make clear that his contemporaries were concerned with the question of how hermits who never appear in the church do receive the Holy Communion. ${ }^{56}$

\section{Arsenius the Great and Socrates}

Texts quoted in the previous section provide some glimpses into reactions which were triggered by hermits radically withdrawing from society in the $4^{\text {th }}-5^{\text {th }}$ century like St. Arsenius. Surely enough, many of them felt also emotional pressure due to the necessity of refusing visitors. This being so, one may wonder what were theological reasons and/or basic justifications of the early Christian secluded way of life.

In order to understand the problem more clearly it would be helpful to make the following point: up to the middle of the $3^{\text {rd }}$ century, the idea of separation from community is invariably seen negatively in Christian texts. ${ }^{57}$ By the second part of the $4^{\text {th }}$ century, the pattern had been completely changed and being alone was now considered to be the most important condition for knowledge of God and salvation. ${ }^{58}$ It would hardly be an exag-

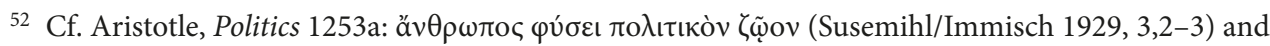
n. 46 above.

${ }^{53}$ Jerome, Letter to Rusticus 125,9,3: solitariam vitam reprehendimus? minime, quippe quam saepe laudavimus. "Do I blame secluded life? By no means, since I have often praised it." Latin text: Hilberg 1996, $128,12-13$. The letter dates back to 412, detailed information about it is to be found in Cain 2010, 151158. Referring to his praise of anachoretic monasticism Jerome possibly thinks about his three Lives of the Hermits: the Life of Paul of Thebes, written in 374 or 375, the Life of Hilarion, written in 390, and the Life of Malchus, written in 391. About these texts see Coleiro 1957.

54 Jerome, Letter to Rusticus $125,9,1$.

55 See Jerome, Letter to Rusticus 125,9.13.16-17.

${ }^{56}$ From a longer apologetic passage I quote only the most essential sentence demonstrating the kind of reasoning of Pseudo-Ephrem: "Being remote in [their] bodies, they (i.e. ascetics living alone in the mountains) do not cease to be sons of the Church but [though absent in the Eucharistic services bodily] they are present [there] through [their] faith." Syriac text: Beck 1973, 34, 26-28. About the Letter to the Mountaineers $\left(5^{\text {th }}\right.$ century?) see Henze $1999,192-193$.

57 See Bumazhnov 2006, Bumazhnov 2008.

58 Cf. a passage by the $4^{\text {th }}$ century monk Ammonas, Letter 12,1: "You also know, my dear brethren, that ever since the transgression came to pass, the soul cannot know God unless it withdraws itself from men and from every distraction." Syriac text: Kmoskó 1915, 603,3-5; translation: Chitty 1979, 16. About St. 
geration to say that between the middle of the $3^{\text {rd }}$ and middle of the $4^{\text {th }}$ century Christianity experienced a revolution which one may call the revolution of the solitaries.

Though a comprehensive treatment of all possible justifications of monastic secluded life does not seem feasible within the scope of this study, ${ }^{59}$ we can try to understand how one of the most outstanding hermits, Arsenius the Great, dealt with this issue using one of his sayings as example.

The saying in question is Ars. 13 which is transmitted in AC, in Arsenius' Life BHG $167 \mathrm{z}$, and in the Greek Systematic Collection (SC). ${ }^{60}$ At least in one case, BHG 167z, available for me in the manuscript Vat. gr. 1589, provides a more reliable text which I take as basis for the following analysis: ${ }^{61}$

Abba Mark said to the blessed Arsenius: "Why do you avoid us, father?" The old man says to him: "God knows that I love you, but I cannot be with God and with men. The ten thousands and thousands of angels have [only] one will, but men have many wills. So I cannot leave God and go with men."

This short dialogue can be easily understood against the background of only Christian sources. As we know, Arsenius persisted in avoiding people including almost all Sketis monks. Speaking to some extent on their behalf and being certainly a bit perplexed and possibly offended Abba Mark ${ }^{62}$ asks about the reason of this behavior.

With the first sentence of his response "God knows that I love you", Arsenius transfers the conversation from matters of everyday life into the theological level. In his perception, Abba Mark questions his fulfilment of the second great New Testament commandment to love one's neighbor. ${ }^{63}$ Facing this challenge Arsenius calls God to witness: "God knows that I love you". Then Arsenius gives an explanation why does he not spend time with his fellow monks provided that he loves them indeed. Not surprisingly, his answer alludes to the New Testament. Saying "The ten thousands and thousands of angels have [only] one will", Arsenius has in mind the third request of the Lord's Prayer: "your will be done, on earth as it is in heaven" ${ }^{64}$ In the $4^{\text {th }}-$ early $5^{\text {th }}$ century, these words were widely understood as referring to the unity of will between angels and human beings. This inter-

Ammonas and his works see Klejna 1938 and Sidorov 1997, 253-257. The connection between being alone and salvation is to be found in the two first sayings of Arsenius the Great, cf. Ars. 1: "Arsenius, flee from men and you will be saved" and n. 29-30 above.

59 I am not aware of any research accounting for reasons of this revolution; about negative attitude towards separation from community in the $2^{\text {nd }}-3^{\text {rd }}$ cent. see two studies referred to in $\mathrm{n} .57$.

60 About this Life see p. 74 above. The SC text is to be found in Guy 2013, 126, 1-7. Ars. 13 texts in AC and SC are almost identical.

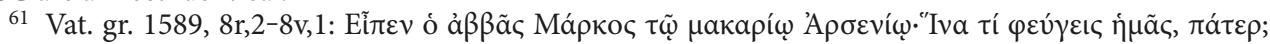

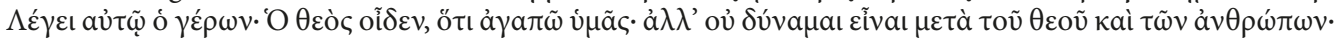

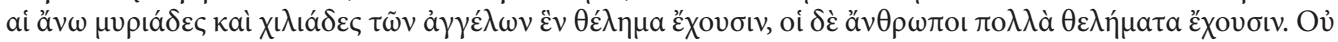

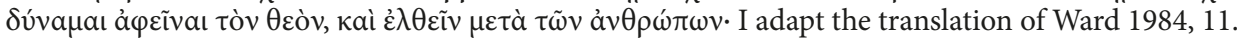

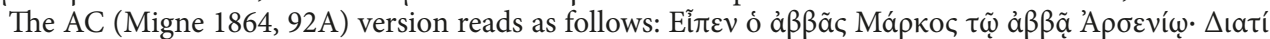

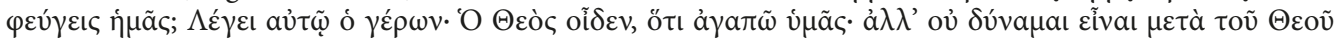

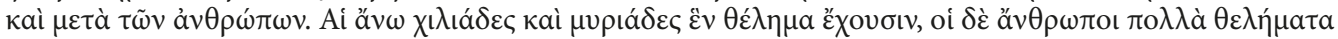

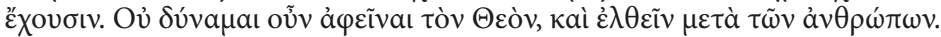

${ }^{62}$ Fife sayings attributed to Abba Mark in AC are probably by him, cf. Migne 1864, 293D-296D and Guy 2013, 62.

${ }^{63}$ Matt. 22:35-40, Mark 12:28-34, Luke 10:25-28.

${ }^{64} M t t .6: 10$, Luke 11:2, translation according to the English Standard Version. 
pretation was so widespread that the bishop of Jerusalem Cyril $(\uparrow 387)$ included it in his catechesis intended for newly baptized Christians. ${ }^{65}$

Thus, Arsenius implies that, when avoiding people, he is acting in the spirit of the most important Christian prayer given by Jesus Christ Himself. And, what is more, he claims to be to a certain degree already united in his will with the angels and, therefore, also with God. This means that Arsenius took seriously the request of unity with the angels in the Lord's Prayer and was trying to live the angelic life which was broadly seen as the goal of all monastic efforts. ${ }^{66}$

The third allusion to the New Testament can be recognized in the final words of Arsenius: "I cannot leave God and go with men". 67 The alternative of following God or human beings is to be found in the book of Acts where it is used twice. ${ }^{68}$ Consequently, Arsenius could have implied that he is acting in the same way as the apostles. ${ }^{69}$ This being said, I would like to emphasize once again that Arsenius' argumentation is completely understandable from its Christian background.

Yet as it seems, there is one more, this time a pagan text that may be used for interpretation of Ars. 13. First of all, it should be pointed out that, more than one hundred and thirty years ago, in his comments on Plato's Apology of Socrates, Louis Dyer proposed to compare Acts 4:19 and 5:29 referred to above ${ }^{70}$ with Socrates' words in Apology 29d: "Men of Athens, I have the warmest affection for you; but I shall obey God rather than you [...]". ${ }^{71}$ This observation has been supplemented and elaborated further by a modern scholar who convincingly argues that, in the Acts of Apostles, the apostle Luke (as the

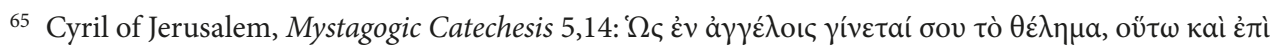

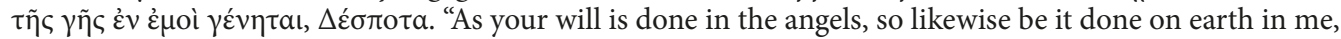
O Lord!" Greek text: Piédagnel 1966, 162,6-7, translation with small modifications according to Cross 1951, 76. This interpretation is to be found in the Homily On Lord's Prayer 4 by Gregory of Nyssa ( $\uparrow$ ca. 386), in the sermon On the Gospel of Matthew 19,5 by John Chrysostom ( $\uparrow 407)$ and in a monastic source with Egyptian background, the Conference 9,20 by John Cassian ( $\dagger$ ca. 432 ).

66 About equation of the ascetic life with "the angelic life" in the early monasticism see Frank 1964, 18-122, Ranke-Heinemann 1964, 65-82, and Muehlberger 2008. It should be noted that in his letter Arsenius addresses himself to "the brethren who have chosen the angelic life", cf. Garitte 1955, 262.

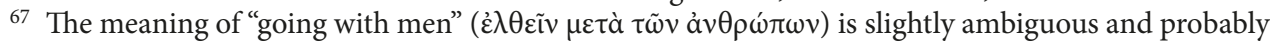
should be understood in the general sense of community of any kind, cf. Alfavitnyj paterik 2009, 39 where this phrase is translated simply as «быть с людьми» ("to be together with people"). Guy 2013, 127 translates literally: "Je ne puis donc abandonner Dieu et aller avec les hommes". According to Bauer 1988, 1031, the preposition $\mu \varepsilon \tau$ tá can be used „zur Bez[eichnung] der Gemeinschaft bei irgend einer Tätigkeit od[er] einem Erleben“. Cf. also the admonition by the fourth- or early fifth-century Egyptian monk Stephen the Theban in the Ethiopic version of his Sermo asceticus 58: "O my son, I entreat you not to walk with the person in whom you find no use, nor with a quick-tempered person. Do not join with a slanderer, do not make friends with a person who is agitated and has a scattered mind, and by no means walk with him. Moreover, do not walk with a man who is befriended with a woman." Ethiopic text: Suciu/Tefera 2019, 496, English translation: ibid., 497.

${ }^{68}$ Cf. Acts 5:29: "But Peter and the apostles answered (i.e. to the members of the Synedrion, cf. Acts 5:27-28): 'We must obey God rather than men"'; Acts 4:19: "But Peter and John answered them (i.e. to the people, the priests, the captain of the temple, and the Sadducees, cf. Acts 4:1), 'Whether it is right in the sight of God to listen to you rather than to God, you must judge"' Translation according to the English Standard Version.

69 As we know from Ars. 1 and 2, Arsenius was commanded to avoid human beings by none other than God, cf. n. 29 and 30 above.

70 Cf. n. 68 above.

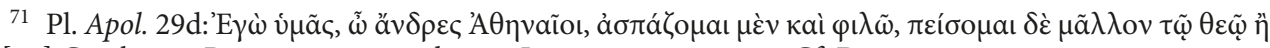

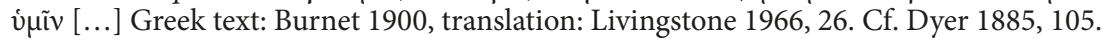


only one of the four Evangelists) purposely puts stress on apostle Peter's lack of education and his obedience to $\mathrm{God}^{72}$ in order to make him similar to Socrates. By doing so Luke intended to portray Christianity as a movement capable of creative assimilation of Greek philosophical ideas. ${ }^{73}$

Against this background, one might observe that, in the two passages from the Acts of Apostles under discussion where Luke highlights that one has to obey God rather than human beings, ${ }^{74}$ we do not find the idea of love towards those whom the apostles have decided to disobey. At the same time, in Apology 29d3, Socrates stresses rather emphatically his fondness of the Athenians. ${ }^{75}$ Now it is worth recalling that Arsenius likewise mentions his love for the fellow monks which he has in some sense to neglect because of love towards God: "God knows that I love you, but I cannot be with God and with men. [...] I cannot leave God and go with men." ${ }^{76}$ We can infer that, apparently, the motif of love in Ars. 13 draws directly on Apology 29d3 independently from Acts 4:19 and 5:29.

A more conjectural connection between Ars. 13 and Apology of Socrates could be established in the following way. Socrates does not want to propose exile $(\varphi v \gamma \eta \dot{\eta})^{77}$ as a penalty which his judges would be willing to impose. He remains in Athens and declines letting him go (å $\varphi \tilde{\varepsilon} v a \mathrm{l})^{78}$ on conditions unacceptable for him. On the contrary, Arsenius flees $(\varphi \varepsilon v ́ \gamma \varepsilon ı v)^{79}$ from his brethren and does not want to leave (ả $\left.\varphi \varepsilon \tilde{v} v a\right){ }^{80}$ God.

Taking into account the noble origin of Arsenius and his prominent position as childhood educator and/or teacher of Emperor's sons, one can safely presume that he was familiar with Plato's Apology which could sometimes have provided him with stylistic guidelines possibly including the case of Ars. $13 .{ }^{81}$ However, neither lexical parallels nor the usage of the same trope of antithesis in both cases necessarily presuppose Arsenius' deliberately referring to Plato's work. Justifying his own secluded way of life Arsenius was primarily guided by the New Testament. When connecting the idea of love for one's neighbor with the imperative of obedience to God even at the expense of this love, Arsenius could have been inspired by the passage from Apology; it cannot be excluded that additional parallels might have contributed to his choice of words. The reference was hardly intended purposely but, nevertheless, Socrates is invisibly present in Ars. 13.

72 This is exactly the point made in Acts 4:19 and 5:29.

${ }^{73}$ Cf. Becker 2020. For Socrates in the early Christian literature, see Panteleev 2013, 679 (bibliography). In addition to this see Benz 1951 and Becker 2020.

${ }^{74}$ Cf. n. 68 above.

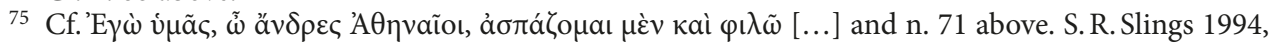

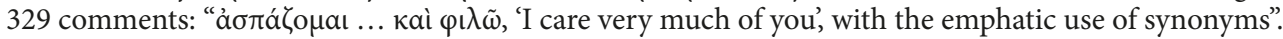

76 Cf. n. 61 above.

77 Pl. Apol. 37c4-5.

78 Pl. Apol. 29c6, 29d2, 30b8.

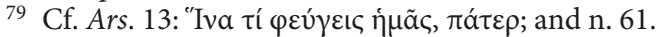

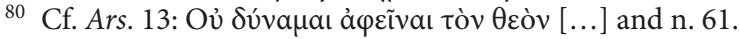

${ }^{81}$ It seems appropriate to recall that Socrates' statement in Apology 29d, "Men of Athens, I have the warmest affection for you; but I shall obey God rather than you", is the absolute climax in Plato's depicting him as the religious man in Apology, cf. West 1979, 166-167 and Slings 1994, 146-149. Surely enough, this point should have been of great importance for another pious man, Arsenius. Thus, Apology $29 \mathrm{~d}$ could have been firmly embedded in Arsenius' mind. 


\section{Conclusion}

Ars. 13 demonstrates that, in the time of St. Arsenius, the justification of the radical eremitical life had just started being seen as a distinct theological problem requiring conceptualization. ${ }^{82}$ As mentioned above, by the end of the $5^{\text {th }}$ - beginning of the $6^{\text {th }}$ century, the compilers of the apophthegmata collections considered this problem as solved to the effect that eremitism surpasses all other forms of monastic life. ${ }^{83}$ St. Arsenius was bound to deal with this problem first and foremost in a practical way. As it appears, he was especially encouraged by the feeling to fulfil the will of God even though he must have been conscious of infringing in some respects upon the interests of his fellow monks. This feeling is exactly what establishes a nexus between Arsenius the Great and the Athenian sage

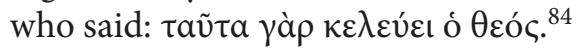

\section{References}

Afinogenov D. E. Some Consideration on the Origin of the Legend about St. Arsenius, the Tutor of the Emperors Arcadius and Honorius. Vestnik drevnej istorii 1 (248), 2004, 49-60. (In Russian)

Alphabetical Patericon or Memorable Stories about Ascetical Devotion of the Holy and Blessed Fathers. Moscow, Sretenskij monastyr', 2009. (In Russian)

Bartelink G. J.M. (ed.) Athanase d'Alexandrie, Vie d'Antoine, Sources chrétiennes 400. Paris, Les Éditions du Cerf, 2004.

Bauer W. Griechisch-deutsches Wörterbuch zu den Schriften des Neuen Testaments und der frühchristlichen Literatur. 6., völlig neu bearbeitete Auflage herausgegeben von K. Aland und B. Aland. Berlin - New York, De Gruyter, 1988.

Beck E. (Hg., Übers.) Des heiligen Ephraem des Syrers Sermones IV, Corpus Scriptorum Christianorum Orientalium 334/335, Scriptores Syri 148/149. Louvain, Secrétariat du Corpus SCO, 1973.

Becker M. Petrus Socraticus: Socratic Reminiscences in Luke's Portrait of Peter. Philologia Classica 2020, 15 (1), 54-71.

Benz E. Christus und Sokrates in der alten Kirche (Ein Beitrag zum altkirchlichen Verständnis des Märtyrers und des Martyriums). Zeitschrift für die neutestamentliche Wissenschaft 1951, 43, 195-224.

Bidez I. (ed.) L'empereur Julien, Euvres complètes, t. I-2e partie, Lettres et fragments. Collection des universités de France publiée sous le patronage de l'Association Guillaume Budé, Paris, Les belles lettres, 1924.

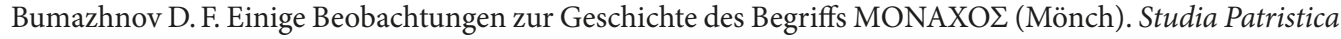
39, 2006, 293-299.

Bumazhnov D. F. Some Ecclesiological Patterns of the Early Christian Period and Their Implications for the History of the Term MONAXO $\Sigma$ (Monk), in: A. A. Alexeev u.a. (Hgg.), Einheit der Kirche im Neuen Testament. Dritte europäische orthodox-westliche Exegetenkonferenz in Sankt Petersburg 24.-31. August 2005, Wissenschaftliche Untersuchungen zum Neuen Testament. Tübingen, Mohr Siebeck, 2008, 251-264.

Bumazhnov D. F. Talking to a Skull between Two Religions. Some Considerations on the History of a Motif in the Christian and Muslim Literature. Simvol 2010, 58, 104-126. (In Russian)

Bumazhnov D. F. Covenant with God and the Making of the Early Christian Monasticism. Philologia Classica. 2017, 12 (1), 12-22.

Burnet I. (ed.) Platonis opera. T. IV. Oxford, Clarendon Press, 1902.

82 This problem is treated in detailed manner by St. Isaac of Nineveh (second part of the $7^{\text {th }}$ cent.) who relies heavily on Arsenius the Great's sayings on which he comments. For English translation from the Syriac original text see Wensinck 1923, treatise 18, p. 104, $\$ 154$; treatise 41 , p. 205-206, $\$ 308-309$. About Isaac (also known as Isaac the Syrian) in general see Chialà 2002.

${ }^{83}$ See p. 76-77 above.

${ }^{84} \mathrm{Pl}$. Apol. 30a5. Needless to say that the case of Arsenius' dealing with radically secluded life was his own case which does not allow us, without further ado, to extrapolate his motivations on the removed monastic past. Nevertheless, Arsenius seems to deliver material for further considerations on the problem of monastic being alone in the $4^{\text {th }}$ and $5^{\text {th }}$ centuries $\mathrm{AD}$. 
Burnet I. (ed.) Platonis opera. T. I. Oxford, Clarendon Press, 1900.

Cain A. The Letters of Jerome. Asceticism, Biblical Exegesis, and the Construction of Christian Authority in Late Antiquity. Oxford Early Christian Studies. Oxford, OUP, ${ }^{2} 2010$.

Caner D.F. "Not of This World": The Invention of Monasticism, in: Ph. Rousseau, J. Raithel (eds), A Companion to Late Antiquity. Malden, MA, Wiley - Blackwell, 2012, 588-600.

Chialà S. Dall'ascesi eremitica alla misericordia infinita: Ricerche su Isacco di Ninive e la sua fortuna, Biblioteca della Rivista di Storia e Letteratura Religiosa, Studi 14. Firenze, Olschki, 2002.

Choat M. The Development and Usage of Terms for "Monk" in Late Antique Egypt, Jahrbuch für Antike und Christentum 2002, 45, 5-23.

Chitty D. J. The Letters of Ammonas, Successor of Saint Antony. Oxford, SLG Press, 1979.

Chitty D. J. The Desert a City. An Introduction to the Study of Egyptian and Palestinian Monasticism under the Christian Empire. St. Petersburg, BIB $\Lambda$ IOПО $\Lambda \mathrm{I} \Sigma$, Publ., 2007. (In Russian)

Cody A. Scetis, in: A. S. Atiya (ed.) Coptic Encyclopedia 7. New York et al., Macmillan, 1991, 2102b-2106a.

Coquin R.-G., Martin M.Dayr al-Qușaye (Țurā), History, in: A. S. Atiya (ed.) Coptic Encyclopedia 3. New York et al., Macmillan Publishing Company, 1991, 853b-854b.

Coleiro E. St. Jerome's Lives of the Hermits. Vigiliae Christianae. 1957, 11, 161-178.

Cremascoli G. Sul genere letterario dei Verba seniorum, in: Frate Egidio d'Assisi. Atti dell'Incontro di studio in occasione del $750^{\circ}$ anniversario della morte (1262-2012), Perugia, 30 giugno 2012, Società Internazionale di Studi Francescani. Spoleto, Centro Italiano di Studi sull' Alto Medioevo, 2014, 19-31.

Cross F. L. St. Cyril of Jerusalem's Lectures on the Christian Sacraments, the Procatechesis and the Five Mystagogical Catechesis. London, S.P.C.K., 1951.

Desprez V. Le monachisme primitif. Des origines jusqu'au concile d’Éphèse, Spiritualité Orientale 72. Bégrolles-en-Mauges, Abbaye de Bellefontaine, 1998.

De Vogüé A. Histoire littéraire du mouvement monastique dans l'antiquité. Première partie: le monachisme latin. Vol. 1: De la mort d'Antoine à la fin du séjour de Jérôme à Rome (356-385). Paris, Les Éditions du Cerf, 1991.

Dyer L. (ed.) Plato, Apology of Socrates and Crito with Extracts from the Phaedo and Symposium and from Xenophon's Memorabilia, College Series of Greek Authors. Boston et al., Ginn \& Company, 1885.

Emlyn-Jones Ch., Preddy W. (eds, transl.) Plato, Republic, Books 1-5. Loeb Classical Library 237. Cambridge Ma, Harvard University Press, 2013.

Evelyn White H.G. The Monasteries of the Wâdi 'n Natrûn. Part II The History of the Monasteries of Nitria and Scetis, The Metropolitan Museum of Art Egyptian Expedition. New York, Arno Press, 1932, repr: 1973.

Faraggiana di Sarzana Ch. Apophthegmata Patrum: Some Crucial Points of their Textual Transmission and the Problem of a Critical Edition. Studia Patristica 1997, 29, 455-467.

Fatti F. Monachesimo anatolico. Eustazio di Sebastia e Basilio di Cesarea, in: G. Filoramo (ed.), Monachesimo orientale. Un'introduzione. Storia 40. Brescia, Editrice Morcelliana SRL, 2010, 53-91.

Festugère A.-J. Les moines d'orient III/1: les moines de Palestine. Cyrille de Scythopolis, Vie de saint Euthyme. Paris, Les Édition du Cerf, 1962.

Frank K.S. АГГЕ $I K O \Sigma$ BIOГ. Begriffsanalytische und begriffsgeschichtliche Untersuchung zum „Engelgleichen Leben" im frühen Mönchtum, Beiträge zur Geschichte des alten Mönchtums und des Benediktinerordens 26. Münster in Westfalen, Aschendorff, 1964.

Frazee Ch. A. Anatolian Asceticism in the Fourth Century: Eustathios of Sebastea and Basil of Caesarea. Catholic Historical Review 1980, 66, 16-33.

Freire J.G. Traductions latins des Apophthegmata Patrum, in: Mélanges Christine Mohrmann. Nouveau recueil offert par ses anciens élèves. Utrecht - Anvers, Spectrum Éditeurs, 1973, 164-171.

Gain B. Le voyage de Basil de Césarée en Orient: hypothèses sur le silence des sources externes. Studia Patristica 95, 2017, 217-224.

Garitte G. Une "Lettre de S. Arsène" en géorgien. Le Muséon 1955, 68, 259-278.

Goehring J. E. "The Origins of Monasticism," in: id., Ascetics, Society, and the Desert. Studies in Early Egyptian Monasticism, Studies in Antiquity and Christianity. Harrisburg, PA, Trinity Press International, 1999, 13-35.

Griffith S. H. Julian Saba, 'Father of the Monks' of Syria. Journal of Early Christian Studies 1994, 2, 185-216.

Griffith S.H. Abraham Qîdūnāyâ, St. Ephraem the Syrian and Early Monasticism in the Syriac-Speaking World," in: M. Bielawski, D. Hombergen (eds). Il monachesimo tra eredità e aperture. Atti del simposio "Testi e tempi nella tradizione del monachesimo cristiano" per il $50^{\circ}$ anniversario dell' Istituto Monastico 
di Sant' Anselmo, Roma, 28 maggio $-1^{\circ}$ giugno 2002. Studia Anselmiana 140. Roma, Pontificio Ateneo S. Anselmo, 2004, 239-264.

Grypeou E. Talking Skulls: On Some Personal Accounts of Hell and Their Place in Apocalyptic Literature. Zeitschrift für antikes Christentum 2016, 20, 109-126.

Guillaumont A. Perspectives actuelles sur les origines du monachisme, in: id. Aux origines du monachisme chrétien. Pour une phénoménologie du monachisme. Spiritualité orientale 30. Bégrolles en Mauges, Abbaye de Bellefontaine, 1979, 111-227.

Guy J.-C. (ed., trans.), Les apophthegmes des pères, collection systématique. Chapitres I-IX. Sources chrétiennes 387. Paris, Les Éditions du Cerf, ${ }^{2} 2013$.

Halkin F. Bibliotheca Hagiographica Graeca. T. 1. Bruxelles, Société des Bollandistes, 1957.

Hall, I. H. The Story of Arsānīs. Hebraica 1889/1890, 6.2, 81-88.

Harmless W. Desert Christians. An Introduction to the Literature of Early Monasticism. Oxford, OUP, 2004.

Henze M. The Madness of King Nebuchadnezzar. The Ancient Near Eastern Origins and Early History of Interpretation of Daniel 4. Supplements to the Journal for the Study of Judaism 61. Leiden, Brill, 1999.

Heussi K. Der Ursprung des Mönchtums. Tübingen, Mohr Siebeck Verlag, 1936 [reprint: Aalen, Scientia Verlag, 1981].

Hilberg I. (Hg.) Sancti Eusebii Hieronymi Epistulae. Pars III: Epistulae CXXI-CLIV, Corpus Scriptorum Ecclesiasticorum Latinorum 56/1, Wien, Verlag der Österreichischen Akademie der Wissenschaften, 1996.

Jiménez Sánchez J. A. La crítica intelectual pagana al monacato primitivo. Sacris Erudiri 2010, 49, 3-35.

Joest Ch. Ein Versuch zur Chronologie Pachoms und Theodoros. Zeitschrift für die neutestamentliche Wissenschaft 1994, 85, 132-144.

Judge E. A. The earliest Use of Monachos for "Monk" (P. Coll. Youtie 77) and the Origins of Monasticism. Jahrbuch für Antike und Christentum 1977, 20, 72-89.

Khosroev A.L. Pachomius the Great (From the Early History of the Coenobitic Monasticism in Egypt). Biblioteka zhurnala Nestor 7. St. Petersburg et al., Nestor-Istoria Publ., 2004. (In Russian)

Klejna F. Antonius und Ammonas. Eine Untersuchung über Herkunft und Eigenart der ältesten Mönchsbriefe. Zeitschrift für katholische Theologie 1938, 62, 309-348.

Kmoskó M. (ed.) Ammonii Eremitae Epistolae, in: Patrologia Orientalis 10, fasc. 6, Paris - Fribourg-enBrisgau, Firmin-Didot, 1915, 555-616.

Leppin H. Theodosius der Große. Gestalten der Antike. Darmstadt, Wissenschaftliche Buchgesellschaft, 2003.

Livingstone R. W. Portrait of Socrates Being the Apology, Crito, and Phaedo of Plato in an English Translation with Introductions and Notes. Oxford, Claredon Press, ${ }^{9} 1966$.

Migne J.-P. (ed.) Patrologiae cursus completus, series prima, in qua prodeunt patres scriptoresque Ecclesiae Latinae. T.73. Paris, apud editorem, 1849.

Migne J.-P. (ed.) Patrologiae cursus completus, series Graeca prior. T. 65. Paris, apud editorem, 1864.

Migne J.-P. (ed.) Patrologiae cursus completus, Patrologiae Graecae T. 31. Paris, apud Garnier fratres, editores et J.-P. Migne successores, 1885.

Moreschini A. "Aresenio". Bibliotheca Sanctorum. Istituto Giovani XXIII nella Pontificia Università Lateranense [vol. 2: Ans-Bern]. Roma, Città Nuova Editrice, 1962, 477-479.

Moreschini A. Introduzione a Basilio il Grande. Brescia, Editrice Morcelliana, 2005.

Muehlberger E. Ambivalence about the Angelic Life: The Promise and Perils of an Early Christian Discourse of Asceticism. Journal of Early Christian Studies 2008, 16, 447-478.

Nagel P. Die Motivierung der Askese in der alten Kirche und der Ursprung des Mönchtums, Texte und Untersuchungen zur Geschichte der altchristlichen Literatur 95, Berlin, Akademie Verlag, 1966.

Palanque J.-R., Bardy G., de Labriolle P. Histoire de l'Église depuis les origines jusqu’à nos jours, vol. 3: De la paix constantinienne à la mort de Théodose. [Paris], Bloud \& Gay, 1947.

Panteleev A. D. Socrates in the Early Christian Hagiography of the $2^{\text {nd }}-4^{\text {th }}$ century. Indo-European Linguistics and Classical Philology 2013, 18, 668-697. (In Russian)

Pauli J. “Apophthegmata Patrum”, in: S. Döpp, W. Geerlings (Hgg.) Lexikon der antiken christlichen Literatur. Freiburg u.a., Herder, ${ }^{3} 2002,52$.

Piédagnel A. (ed.) Cyrille de Jérusalem, Catéchèses mystagogiques, Sources chrétiennes 126. Paris, Les Éditions du Cerf, 1966.

Price R. M. (trans.) Lives of the Monks of Palestine. Kalamazoo, Cistercian Publications, 1991.

Ranke-Heinemann U. Das frühe Mönchtum. Seine Motive nach den Selbstzeugnissen. Essen, Hans Driewer Verlag, 1964. 
Raynor D. H. Non-Christian Attitudes to Monasticism. Studia Patristica 1987, 18/2, 267-273.

Rousseau Ph. Basil of Caesarea. The Transformation of Classical Heritage 20. Berkeley et al., University of California Press, 1994.

Rubenson S. The Formation and Re-formation of the Sayings of the Desert Fathers. Studia Patristica 2013, $55,5-22$.

Saunders T. J. Aristotle, Politics, Books I and II. Clarendon Aristotle Series. Oxford, Clarendon Press, 1995, repr. 2000.

Sidorov A. I. St. Ammonas: His Person and His Works. Bogoslovskie trudy 1997, 33, 253-312. (In Russian)

Schwartz E. (ed.) Kyrillos von Skythopolis, Texte und Untersuchungen zur Geschichte der altchristlichen Literatur 49. Leipzig, J. C. Hinrichs Verlag, 1939.

Silvas A.M. The Asketikon of St Basil the Great, Oxford Early Christian Studies. Oxford, OUP, 2005.

Slings S. R. Plato's Apology of Socrates. A Literary and Philosophical Study with a Running Commentary Edited and Completed from the Papers of the Late E. de Strycker, S. J., Mnemosyne. Bibliotheca Classica Batava. Leiden et al., Brill, 1994.

Smith Z. B. Philosopher-Monks, Episcopal Authority, and the Care of the Self. The Apophthegmata Patrum in Fifth-Century Palestine, Instrumenta Patristica et Mediaevalia 80. Turnhout, Brepols, 2017.

Suciu A., Tefera A. The Ethiopic Version of Stephen the Theban's Sermo asceticus. Le Muséon 2019, 132 (3-4), 475-507.

Susemihl F., Immisch O. (Hgg.) Aristotelis Politica. Editio altera correctior. Leipzig, Teubner, 1929.

Teja R. Los origenes del monacato y su consideracion social. Codex Aquilarensis. Revista de Arte Mevieval: Cuadernos de Investigación del Monasterio de Santa Maria la Real 1988, 2, 11-31.

Tetz M. Eine asketische Ermunterung zur Standhaftigkeit aus der Zeit der maximinischen Verfolgung (311/313). Zeitschrift für die neutestamentliche Wissenschaft 1990, 81, 79-102.

Timm St. Das christlich-koptische Ägypten in arabischer Zeit. Eine Sammlung christlicher Stätten in Ägypten in arabischer Zeit, unter Ausschluß von Alexandria, Kairo, des Apa-Mena-Klosters (Dèr Abü Mina), der Skētis (Wädi n-Națrūn) und der Sinai-Region. Beihefte zum Tübinger Atlas des Vorderen Orients, Reihe B, Nr. 41/6, Teil 6 (T-Z). Wiesbaden, Ludwig Reichert Verlag, 1992.

Vasil'evskii V. G. Symenon the Metaphrast's Synodal Codex. Journal of the Ministry of the People's Enlightenment 1897, 311, 332-375. (In Russian)

Vasil'evskii V. G. Symenon the Metaphrast's Synodal Codex. St. Petersburg, Tipografiia V. S. Balašev i K Publ., 1899. (In Russian)

Ward B. The Sayings of the Desert Fathers. The Alphabetical Collection. Cistercian Studies 59. Kalamazoo, Cisterian Publications, Revised Edition, 1984.

Weis B. K. (ed., trans.) Julian, Briefe. München, Heimeran Verlag, 1973.

Wensinck A. J. (trans.) Mystic Treatises by Isaac of Nineveh Translated from Bedjan's Syriac text with an Introduction and Registers, Verhandelingen der Koninklijke Akademie van Wetenschappen te Amsterdam, Afdeeling Letterkunde, Nieuwe Reeks, Deel 23,1. Amsterdam, Koninklijke Akademie van Wetenschappen, 1923.

West Th. G. Plato's Apology of Socrates. An Interpretation, with a New Translation. Ithaca - London, Cornell University Press, 1979.

Wipszycka E. Quand a-t-on commence à voir les moines comme un groupe à part? Pour comprendre "Vita Antonii" 46, 2-5. The Journal of Juristic Papyrology 1997, 27, 83-92.

Wipszycka E. P. Coll. Youtie 77= P. Coll. VII 171 Revised, in: T. Gagos, R. S. Bagnall (eds). Essays and Texts in Honor of J.D. Thomas. American Studies in Papyrology 42, Oakville, The American Society of Papyrologists, 2001, 45-50.

Received: November 01, 2019

Accepted: March 17, 2020 